WoJCIECH KLePUSZEWSKI

Politechnika Koszalińska

\title{
"Some Corner of a Foreign Field That Is [Not] For Ever England": Brexit and Poetry
}

Quoting Rupert Brooke's plea to remember that there is "some corner of a foreign field that is for ever England" (23) may at first seem misplaced in the Brexit context, especially that mourning the English soldiers who laid their lives in France is all but on a par with contemplating the potential trials and tribulations caused by Britain divorcing the EU. Yet, if stripped of its historical background, the elegiac tone of the line offers a convenient point of departure for a discussion embracing both the grieving losers of the referendum and the enthusiastic Brexiteers, the two groups of adherents respectively losing/wining by margin (hence the modest "not" in the title of this article).

However, Brooke's sonnet is employed here for another, more important reason. This is so because the 1914-1918 period triggered a phenomenal poetic response, not only by the several distinguished poets commemorated on the slab at the Poets' Corner in Westminster Abbey, and not even by the soldiers who wrote poems while on active service in France, ${ }^{1}$ but by civilians who contributed a flood of war-related verse. A similar surge of public interest in poetry has been taking place since the 2016 Brexit referendum, though the thematic scope is obviously incomparable in terms of its gravity. However, this article is not an attempt to compare the two, but, by drawing on the example provided

1 See Anne Powell (200o). 
by the poetic phenomenon of the Great War, examine the phenomenon of Brexit poetry written by ordinary citizens at this particular turning point in the nation's history.

Brexit has so far generated enormous media coverage as well as a multitude of analytical publications, but, most importantly here, it has also been mirrored in what Harald Pittel calls an "emergent strand of literature" (58), ${ }^{2}$ otherwise labelled Brexlit, a blend now commonly used. Literary intersections involving Brexit have been the focus of research discussed in various studies, including Brexit and Literature (2018), edited by Robert Eaglestone. John Sutherland goes as far as to suggest a "ВА Honours degree in Brexit-related literature" (2018:20), which should be taken with a pinch of salt, though admittedly, Brexlit as such is already a topic students choose for theses and dissertations. ${ }^{3}$

However, while much interest is devoted to fiction thematising Brexit, far less attention has been paid to poetry. This may seem surprising, because poetry is particularly relevant in the Brexit context. First of all, fiction does not possess the "swiftness" of poetry, as the brevity of expression offered by poetry has an obvious advantage over the narrative length and complexity of fiction. Secondly, unlike fictional works, poetry is not constrained by the time lapse between writing and publishing, particularly with the availability of social media, owing to which a poem can be twittered, facebooked or blogged/vlogged as soon as it is written. Such immediacy allows poetry to become, figuratively, a heartbeat monitor of a sort, reacting to events as they happen. As Katy Shaw puts it, social media and accessible technology greatly contribute to "magnifying its impact" (qtd. in Gunn 2019).

On the other hand, such immediacy has obvious drawbacks, for any rhymester may be tempted to use social media in order to circulate lines remotely resembling poetry. This applies in particular to the verse written by ardent Brexit supporters, most of it reminiscent of the infamous jingoism written by poetasters and armchair poets at the initial phase of the Great War. ${ }^{4}$ A good example of Brexiteers' triumphant doggerel is "Brexit":

2 The very same, though in a far more limited dimension, applies to various arts. Neil Archer's Cinema and Brexit (2020), for instance, discusses representation of Brexit in British cinematography. A good example of Brexit's impact on arts is Brexit Tears (2020), a joint project by Robert Crawford, a poet, and Calum Colvin, a photographer, in which "[w]ords and images talk to each other through forceful but ambiguous meanings" (Riach 2020).

3 A good example is Sara Alessio's doctoral dissertation defended at Bologna University, Reading Brexit Through BrexLit: Fictional Responses to Political Crisis (2020).

4 See Wojciech Klepuszewski (2006). 
Cast off your gloom, Remainers!

Rejoice the brand new day.

Britain can be great again. (Butters)

Such verse is often written under a pseudonym, as in "Brexit Song Sing It (Go West)," crowned with a complacent "it's just Great being from Britain" (Trim). It is probably this kind of response, glorifying Brexit and rejoicing at the results of the referendum, which prompted Christopher Hope, assistant editor of The Daily Telegraph, to invite readers to contribute a poem about Brexit, he himself twittering one to encourage them and set the "proper" example. Hope tries to achieve this by hitting the patriotic note, as in the image of "red poppies," inevitably evoking the Great War:

Red for the poppy, brave and bold Blue for the passport, so proud to hold

White for the flag we wave as we exit

Thank God for Mrs May and our glorious Brexit. (Hope)

This, however, met with little reaction, at least not the kind which Hope had expected. As Jonathon Read explains, "[t]he problem was that most of the responses received didn't come from the pro-Brexit supporters that rally behind their newspaper, but Remainers responding in their masses with their own unique take on Britain leaving the EU" (2018). Hope's failure led David Wheatley to ponder " $[\mathrm{w}]$ here are the pro-Brexit bards?", to which he provides the following answer: "there is simply no poetry to be written about the merits of Brexit. As we are reminded every time Gove, Farage, Johnson and co open their mouth, Brexit is a place where language goes to die" (2018). Indeed, literature is a domain in which the Brexiteers are completely outnumbered, so Richard Kelly's conclusion that Brexit fiction is "minded to Remain" (2018: 77) applies likewise to poetry. In a manner of consolation for those who outvoted the supporters of the Eu, yet failed to give it a literary voice, John Sutherland offers The Good Brexiteer's Guide to English Lit (2018), of which John Crace writes in the preface that its author "has given [Brexiteers] all a cultural and literary hinterland around which they can unite and against which Brexit can be better understood" (11).

As far as poetry is concerned, it has to be acknowledged that most of it resulted from a poetic levy in mass, as it were, with citizens voicing their emotions in verse daily. This said, one should mention the prominent literary figures who did respond to Brexit in their poetry, such as the last three Poets Laureate: 
Andrew Motion, Carol Ann Duffy and Simon Armitage respectively. Andrew Motion wrote a contemplative "After the EU referendum: "In the Air" (2016), Carol Ann Duffy, by contrast, in "A Formal Complaint" (2019) launches a vehement attack on Brexitmongers, employing diction which might be considered rather "sweary for a poet laureate" (Allardice 2018), to quote "the bullshitters who pose and pontificate" or "midgies biting their arseholes" (24).5 Finally, Simon Armitage, the present Poet Laureate, whose "The Brink" touches upon a multitude of issues concerning Brexit. The poem has a strong sense of déjà $v u$ about it, for much like Tony Harrison's "V," broadcast by Channel 4 in 1987, it is read by its author on screen with simultaneously appearing images. One might argue whether "The Brink" is derivative, or merely inspired by Harrison's poem, but it has certainly not stirred as much controversy and attention as "V."

The few responses from the sanctioned pedestal of the Poets Laureate are outnumbered by less distinguished poets. Vidyan Ravinthiran's "Brexit" in The Million-Petalled Flower of Being Here (2019), Hugh Dunkerley's "Referendum" in Kin (2019) are singular examples, but the title of David Clarke's collection, The Europeans (2019), immediately signals its predominant focus. The picture would not be comprehensive without acknowledging the poetic contribution of those whose ethnic background is mixed. One such poet is Anthony Anaxagorou, a British-born Cypriot, author of After the Formalities (2019). In "Cause," one of the poems included in the collection, Anaxagorou provides his own definition of identity, certainly alien to Brexiteers: "to be British is to be everywhere" (17). A related collection of poems, this time inviting voices from non-UK-born writers is Wretched Strangers: Borders Movement Homes (2018), edited by Ágnes Lehóczky and JT Welsch. Finally, an idiosyncratic publication, which only proves that poetic responses to Brexit are both abundant and diverse. The case in point is Nicholas Hagger's attempt to follow the tradition of mock-heroic in Fool's Paradise: The Voyage of a Ship of Fools from Europe. A Mock Heroic Poem on Brexit (2020).

All the poets mentioned so far are, to a different extent, established literary figures, but the core of poetic voice given to Brexit comes from those whose relationship with poetry is limited to being occasional readers. They, much as the thousands of ordinary citizens during the Great War, decided to vent their

5 Duffy's contribution to Brexit poetry is also My Country: A Work in Progress; In the Words of People Across the UK (2017), a joint project with Rufus Norris, the artistic director of the National Theatre, which Paul Taylor describes as "as a verbatim postBrexit cantata, drawn from interviews with people nationwide, ranging in age from 9 to 97 " (Taylor 2017). 
despair and anger by means of poetic diction. A multitude of examples can be found in various social media, particularly Twitter, which, as Lee Moran observes, has been flooded with poems reminiscent of the Hamletian dilemma, here denoting the leave or remain question: "Hundreds of people have now penned rhymes to express their feelings on the Brexit, with the majority (but not all) lamenting the vote to leave" (2016). In most cases such twittered verse is incidental, whereas blogs usually offer a range of poems, a good example being Keith Murphy's blog, much of which is devoted to Brexit, including almost 200 sonnets and "Brexit parodies" (Murphy). While some blogs remain fairly obscure, others, such as that run by Brian Bilston are quite popular with the readers. Bilston, referred to on his website as the "Poet Laureate of Twitter," appears to be often quoted, particularly " 57 Varieties of Brexit," reflecting its complexity by means of compound modifiers, to quote but a few: "Bear-it-witha-grin Brexit / Big-bus-with-a-lie Brexit / What-was-life-before Brexit / Makesme-want-to-cry Brexit / Just-think-of-any-word Brexit / Brexit-Brexit-Brexit Brexit" (Bilston). By employing such diction Bilston not only emphasises the complexity of Brexit, but also its omnipresence, as it were, in the public, social, and emotional domains.

Although the poetic voice of the public is predominantly channelled in a more personal capacity through social media, what helps trigger the massive response are various projects and campaigns. One such venture, established in May 2019, is Places of Poetry, which enables anyone to post their poem on a digital map of England and Wales. As one of the project's leaders explains, initially it was not intended to specifically invite Brexit-related poems, but it became a covenient means of posting them:

Like many people across the country, we did not seek Brexit, but rather it was thrust upon us. We began planning Places of Poetry before Brexit was even a word, and even when we settled on the summer of 2019 we assumed that our European traumas would have been resolved. Over the last three years the problems and angst have only grown, and when Boris Johnson nailed his and the nation's future to 31 October, we decided that we had to extend this zeitgeist project accordingly. (McRae)

Much the same can be said of the Poetry Box Project, little tins left in different places in Exmoor, containing a book, a pencil and a sharpener, to allow anyone who happens to be in the area to add something, the something usually being verse. Some of it has a chance to reach a wider audience, because, as Alison Flood reports, "[m] ore than 6,00o poems, including ones about Brexit and 
marriage proposals, left in boxes over the last three years, will be considered for publication" (2016).

Most verse posted by all those who might be tagged as "temporarily self-appointed poets" expresses anger, bitterness or disappointment. One distinguishable strand is the portrayal of Brexit as an obsession with anything foreign. This is often reflected in verse which can be quite droll, a good example being "Exit," Kevin Higgins's dystopian vision:

Those alleged to be involved in secretly

making spaghetti bolognaise

will be arrested and held

in a detention centre near Dover.

Neatly sliced

French sticks topped with pâté

will make way for fried bread

lathered with Marmite. (2017)

As can be seen, part of the humour is based on food imagery, recurrent in Brexit-related verse. This is exactly what Henry Normal does in "Cake (A poem with layers)," a symbolic farewell to all that is not British: "French Pastries ... Battenberg and Blackforest Gateau, ... Swiss Roll ... Panettone ... or anything European like Tiramisu" (Normal). In a similar vein, Brian Bilston in "Brexit in Pursuit of a Bear" employs Paddington Bear and his craving for marmalade in order to mock the Brexiteers' allergy to anything non-British:

He's one of those funny foreign types

who try to come here nowadays,

to take our homes and steal our jobs

and eat Our Great Nation's Marmalade. (Bilston)

Joseph Birdsey, on the other hand, in "Pencil Drawn Borders" uses similar imagery to pinpoint the hypocrisy of Brexitmongers:

Robert tells me over curry

I'm sick of immigration, stuffs Masala in his mouth and sips his cup of tea. (Birdsey) 
Birdsey's poem is available on Young Poets Network, whose authors as well as target readers are adolescents and young adults, a group overwhelmingly supporting the EU. This age group is an ideal audience to be reached by various "commentators" who fuse poetry with sound and music. One such performer is Kate (Kae) Tempest, described by Damian Jones as a "raper and spoken word artist," whose "Europe is Lost" and "People's Faces" is poetry performed rather than recited, all to the background beat. Similar artists who present their poetry during live shows or post it on the Internet are Luke Wright and Hollie McNish, but unlike Tempest's, their stage shows consist of long rhythmical recitals. Luke Wright addresses Brexit in "The Panel," the closing line, "Britain, smitten on a lie" (Wright), exposing the true nature of the pre- and post-Referendum turbulence. In a similar manner, Hollie McNish passionately manifests her standpoint in "British National Breakfast" and "Foreign":

I find it strange we're ok with chewing on foreign food

Chinese carry out bags and Indian too,

kebabs and pizzerias and foreign tropical fruit juice.

We're ok with eating foreign sugar cane sugary treats,

Munching on foreign cocoa bean chocolaty sweets,

Complaining between every bite about the foreign folk down our street. (McNish)

Much as in the case of Joseph Birdsey's poem quoted earlier, McNish pinpoints the hypocrisy and contradiction inherent in the concept of Brexit, a pitfall into which most of its avid supporters fall, apparently blind to the fact that what constitutes modern Britishness is ethnically and culturally diverse and multifaceted.

\section{Conclusion}

As the survey presented above clearly shows, Brexit-related poetry is a phenomenon of a sort, in which exceptional literary calibre is not of ultimate importance, for its primary value lies in the fact that it relects the voice of ordinary people. More to the point, although poems addressing important political and social upheavals are not hard to find in British literature, to mention Adrian Mitchell's “To Whom it May Concern," first read during the Vietnam War protest in Trafalgar Square in 1964, such poems are singular cases, rather than part of a poetic outpouring. This stands in sharp contrast to the phenomenal number of verse contributed by the public during the Great War, as well as the response 
which is taking place in the aftermath of the Brexit referendum. The Great War produced a poetic mobilisation of a sort which did not take place again during World War Two. ${ }^{6}$ Yet, a century later, a similar phenomenon repeats itself, with a flood of poetry written by the public concerned with Brexit.

In his poem titled "In Memory of W. B. Yeats" (1939), W. H. Auden, possibly quite provocatively, claims that "poetry makes nothing happen" (50). Whether this applies to Brexit poetry is arguable, but the fact is that, as Ambrose Musiyiva writes in the preface to Bollocks to Brexit: An Anthology of Poems and Short Fiction, "poetry responds" (ii). In the case of Brexit, much as during the Great War, poetry proves to be a means of public response, but also, as Rhianon Cosslett puts it, "an antidote, illuminating where political commentary falls short" (2019). What supports this claim is the fact that poetry sales in Britain have gone up recently (Ferguson 2019), which might be a signal that the same has happened to sensibility and social/political awareness.

\section{| Works Cited}

Allardice, Lisa. "Interview: Carol Ann Duffy." The Guardian 27 Oct 2018.

Allesio, Sara. Reading Brexit Through BrexLit: Fictional Responses to Political Crisis, 2020, http://amsdottorato.unibo.it/9427/. Accessed o7 April 2021.

Anaxagorou, Anthony. After the Formalities. London: Penned in the Margins, 2019.

Anne Varty. "Poetry and Brexit." Brexit and Literature: Critical and Cultural Responses. Ed. Robert Eaglestone. Abingdon: Routledge, 2018. 59-65.

Archer, Neil. Cinema and Brexit. London: Bloomsbury Academic, 2020.

Armitage, Simon. "The Brink." www.skyartsart5o.tv/projects/thebrink/. Accessed 24 March 2021.

Auden, W. H. The Collected Poetry of W. H. Auden. New York: Random House, 1945 .

Bilston, Brian. " 57 Varieties of Brexit." https://brianbilston.com/2017/o6/18/57-varieties-of-brexit/. Accessed 15 March 2021.

---. "Brexit in Pursuit of a Bear." https://tinyurl.com/2p45b35a. Accessed o6 March 2021.

6 This fact led Robert Graves to ponder "[w]hy has this War produced no War Poets?" (310). 
Birdsey, Joseph. "Pencil Drawn Borders." https://tinyurl.com/487bw2yd. Accessed 28 March 2021.

Brooke, Rupert. The Poetical Works. London: Faber and Faber, 1970.

Butters, Paul. "Brexit." https://hellopoetry.com/words/brexit. Accessed 19 April 2021.

Clarke, David. The Europeans. Rugby: Nine Arches Press, 2019.

Colvin, Callum and Robert Crawford. Brexit Tears. Newtyle: Kettilonia, 2020.

Cosslett, Rhianon Lucy. "Brexit Poetry May not Heal our Divided Nation, but it Helps." Guardian 7 Nov. 2019.

Crace, John. "Preface." The Good Brexiteer's Guide to English Lit. John Sutherland. London: Reaktion Books, 2018. 11-16.

Duffy, Carol Ann. Sincerity. London: Picador, 2019.

Dunkerley, Hugh. Kin. Blaenau Ffestiniog: Cinnamon Press, 2019.

Eaglestone, Robert, ed. Brexit and Literature: Critical and Cultural Responses. London: Routledge, 2018.

Ferguson, Donna. "Poetry Sales Soar as Political Millennials Search for Clarity." The Guardian 21 Jan. 2019.

Flood, Alison. "Brexit Poems and Dirty Limericks: Poetry Left in Boxes Across Exmoor to Be Compiled for Book." The Guardian 7 Sept. 2016.

Graves, Robert. The Common Asphodel: Collected Essays on Poetry 1922-1949. (1949). London: Hamish Hamilton, 1949.

Gunn, George. “The Silent Poetry of Brexit.” Bella Caledonia 31 Jan. 2019. Hagger, Nicholas. Fool's Paradise: The Voyage of a Ship of Fools from Europe. A Mock Heroic Poem on Brexit. Alresford: John Hunt Publishing, 2020.

Harrison, Tony. $V$. Newcastle upon Tyne: Bloodaxe, 1985.

Higgins, Kevin. "Exit, a Brexit Poem by Kevin Higgins." The Irish Times 5 Dec. 2017.

Hope, Christopher. https://twitter.com/hashtag/BrexitPoems?src=hashtag_click. Accessed o3 April 2021.

Kelly, Richard T. "Brexit in Fact and Fiction." Critical Quarterly 60.2 (2018): 74-85. Klepuszewski, Wojciech. The Missing Chapter-Women's Poetry of the Great War. Koszalin: Wydawnictwo Politechniki Koszalińskiej, 2006.

Lehóczky, Ágnes and Welsch, J. T., eds. Wretched Strangers: Borders Movement Homes. Norwich: Boiler House Press, 2018.

McNish, Hollie. "British National Breakfast." https://tinyurl.com/yym26d8r. Accessed 15 March 2021.

---. "Foreign." https://derbynews.org.uk/2014/o3/30/foreign-by-hollie-mcnish/. Accessed 14 March 2021.

McRae, Andrew. https://www.exeter.ac.uk/news/university/title_749467_en.html. Accessed 10 March 2021. 
Meyer, Michael, ed. The Collected Poems of Sidney Keyes. London Routledge\&Kegan Paul, 1945.

Mitchell, Adrian. Tell me Lies: Poems 2005-2008. Tarset: Bloodaxe, 2009.

Moran, Lee. "Britons Turn To Poetry To Express Their Feelings On Brexit.” The Huffington Post, 26 June 2016.

Motion, Andrew. "After the Eu Referendum: In the Air." The Guardian 2 July 2016.

Murphy, Keith. K.R. Murphy: Official Site of Sometime Author \& Poet, https://keithmurphy26.wixsite.com/blog. Accessed 22 March 2021.

Musiyiva, Ambrose, ed. Bollocks to Brexit: An Anthology of Poems and Short Fiction. CivicLeicester, 2019.

Normal, Henry. "Cake (A poem with layers)." https://www.northernsoul.me.uk/henry-normal-brexit-poem. Accessed 6 March 2021.

Pittel, Harald. "Fiction in Dark Times: the Brexit Novel and Ali Smith," Hard Times 101.1 (2018): 58-67.

Powell, Anne, ed. A Deep Cry: First World War Soldier-Poets Killed in France and Flanders. Stroud: Sutton Publishing, 2000.

Ravinthiran, Vidyan. The Million-Petalled Flower of Being Here. Hexham: Bloodaxe, 2019.

Read, Jonathon. "The Telegraph Asks for Brexit Poems and It All Goes Wrong." The New European 1 May 2018.

Riach, Alan. "Review of Brexit Tears." The National 3 Aug 2020.

Sutherland, John, ed. The Good Brexiteer's Guide to English Lit. London: Reaktion Books, 2018.

Taylor, Paul. "My Country; A Work in Progress, Dorfman, National Theatre, review: Carol Ann Duffy Brings a Major's Poet's Ear to the Music of the Text." The Independent 13 March 2017.

Tempest, Kate (Kae). "Europe is Lost.” https://tinyurl.com/8rx3bs. Accessed 14 March 2021.

---. "People’s Faces.” https://tinyurl.com/442p5b8e. Accessed 14 March 2021.

Trim. "Brexit Song Sing It (Go West)." https://allpoetry.com/poems/about/brexit. Accessed 18 April 2021.

Wheatley, David. "Poetry in the Age of Brexit." The Irish Times 23 Jan. 2018.

Wright, Luke. “The Panel." https://www.lukewright.co.uk/the-panel-edit/. Accessed 14 March 2021. 


\section{| Abstract \\ WOJCIECH KLEPUSZEWSKI \\ "Some Corner of a Goreign Gield That Is [Not] For Ever England": Brexit and Poetry}

Although it would be absurd to compare the 2016 Brexit referendum and whatever happened in its aftermath to the tragedy of the Great War, surprising as it may seem, the two have something in common. This is so because the 1914-1918 period triggered a flood of poetry, written not only by established literary figures, but also by thousands of civilians who found it a means of expressing their emotions. By the same token, the post-referendum years produced a poetic response on the part of ordinary citizens. This article tries to take a closer look at how once again British citizens turn to poetry to voice their fears and frustration.

Keywords: Great War; poetry; Brexit; Brexlit

\section{| Abstrakt}

WOJCIECH KLEPUSZEWSKI

„Skrawek obcej ziemi, który [nie] na zawsze pozostanie Anglią”: brexit i poezja

Chociaż porównanie referendum z 2016 roku o wyjściu Wielkiej Brytanii z Unii Europejskiej do I wojny światowej wydawałoby się absurdalne, te dwa okresy mają ze sobą coś wspólnego. Wynika to z faktu, iż okres lat 1914-1918 wywołał lawinę poezji tworzonej nie tylko przez uznanych poetów, ale także przez tysiące zwyczajnych Brytyjczyków, dla których poezja była sposobem na wyrażenie własnych emocji. W podobny sposób okres po referendum spowodował masową reakcję zwykłych obywateli. Prezentowany artykuł podejmuje próbę przyjrzenia się temu, jak raz jeszcze Brytyjczycy wykorzystują poezję do wyrażenia swoich obaw i frustracji.

Słowa kluczowe: I wojna światowa; poezja; brexit; brexlit

\section{| About the Author}

Dr hab. Wojciech Klepuszewski is Associate Professor at the Faculty of Humanities, Koszalin University of Technology, Poland. His recent research comprises mainly 
the theme of drink in literature, which is the focus of his book The Proof is in the Writing: Kingsley Amis's Literary Distillations (2018). His latest publication is an edited work (with Dieter Fuchs and Matthew Leroy) Booze as a Muse: Literary and Cultural Studies of Drink (2021).

E-mail: wklepuszewski@web.de

ORCID: 0000-0003-3720-988x 